\title{
Ownership Structure and Firm Performance: An Empirical Analysis of Chinese Companies
}

\author{
Hui Zhang ${ }^{1}$, Khine Kyaw ${ }^{2}$ \\ ${ }^{1} \mathrm{PhD}$, China Association for Public companies, New Era Building, Xi Cheng District, Beijing, 100034, China \\ ${ }^{2}$ Associate Professor, NTNU Business School, Norwegian University of Science and Technology, Klaebuveien 72, 7030, \\ Trondheim, Norway
}

Correspondence: Khine Kyaw, Associate Professor, NTNU Business School, Norwegian University of Science and Technology, Klaebuveien 72, 7030 Trondheim, Norway.

Received: December 2, 2016

doi:10.11114/aef.v4i2.2109

\author{
Accepted: December 23, $2016 \quad$ Available online: December 26, 2016 \\ URL: http://dx.doi.org/10.11114/aef.v4i2.2109
}

\begin{abstract}
This study examines the relationship between ownership structure and firm performance in Chinese companies. We hand collected ownership data on 1178 non-financial companies with a total of 5815 firm-years from annual reports. Through fixed-effect panel model, this study has the following findings. First, there is a positive relationship between firm performance and institutional ownership in Chinese companies. Second, the proportion of tradable shares negatively affects firm performance. Third, ownership concentration and state ownership appear to not affect firm performance.
\end{abstract}

Keywords: state ownership, institutional ownership, tradable shares, firm performance, China

JEL classifications: G10, G15, G18, G32

\section{Introduction}

One feature of the modern listed companies is the wide-spread ownership structure. Shareholdings of various shareholders generate the conflicts of interest among shareholders, thereby influencing firm performance of companies. Thus, appropriate ownership structure may support companies to have a good performance in market. For instance, although concentrated ownership by institutional owners can bring a positive effect on firm performance (Elyasiani and Jia, 2010), inappropriate level of ownership concentration can bring negative effects on firm performance (Dahya et al., 2008). The political shareholding can also have negative impact on firm performance (Chang and Wong, 2004).

Ownership structure of Chinese listed companies can be characterised by the ownership concentration and the political shareholdings. A centrally planned economic regime used to dominate Chinese market for decades. During that period, the only legal economic entities in the Chinese market were the state owned companies. The state simultaneously worked as the owner and managers in these companies. Then the Chinese government decided to abandon the economic regime at the end of $1970 \mathrm{~s}$, and since then the government has been trying to move the economy towards a market oriented economic regime. During this process, the ownership began to be separated from control. Some state owned companies have been sold to private investors. The stock exchanges have been established to allow companies raise fund through issuing stocks. Because of those changes, the ownership structure of Chinese companies has become diversified.

However, the ownership of Chinese companies has several drawbacks. One of them is the prevalence of state ownership. As the founding shareholder, the proportion of state shareholdings remains high. Studies have shown that state ownership can negatively influence firm performance of Chinese companies (see for example Chen et al., 2007). Additionally, the stock segmentation harms the liquidity of Chinese market, since most of the available shares are non-tradable shares that cannot be trade in the market (Berkman et al., 2009). The stock segmentation prohibits the market mechanism from improving Chinese companies' performance (Huang and Fung, 2005; Tomasic and Fu, 2006).

At the end of 2005, market regulators started a series of reforms of ownership structure to improve on the weaknesses of ownership structure of Chinese companies. One of the reforms is to gradually convert the non-tradable shares into tradable shares (Ng et al., 2009). Non-tradability of shares can lead to poor performance in firms as studies have shown 
that directors' compensation and related-party transactions are positively correlated with non-tradability of shares (see for example Yeh et al., 2009).

To examine the relationship between ownership structure and firm performance as firms are being reformed, this study employs a sample of 1178 non-financial companies from 2004 to 2008. Through the use of fixed-effect model that controls for potential endogeneity in the data, this study uncovers the followings. First, similar to the findings from other markets, institutional ownership has positive effects on firm performance in Chinese companies. Second, contrary to expectation there is a negative relationship between the proportion of tradable shares and firm performance. This could be due to the market being at an early stage of its development. Young financial markets tend to host relatively less sophisticated investors (Zhang et al., 2010), a situation which could exacerbate the problem of free-riders. Consequently, firm performance impairs as more tradable shares become available. Finally, state ownership and ownership concentration do not appear to affect firm performance in Chinese companies. State ownership may divert firm objectives to social performance, yet providing better access to the resources the firm needs. This situation may have created opposing effects on the firm's performance which eventually cancel off each other leaving no net effect on the firm's performance. Ownership concentration may reduce the conflicts of interest between shareholders and managers, but it may also exacerbate the conflict of interest among shareholders (López-de-Foronda et al., 2007; Chen-Lung et al., 2009). This might explain the apparent absence of significant relationship between the ownership concentration and firm performance.

The Chinese market is very well suited for a study on the effects of ownership structure and share tradability as it offers a natural experiment. This study contributes to the literature on firm performance in a number of ways. First, this study explores the effect tradability of shares has on firm performance when a market is in its early stage of development. Secondly, the study investigates the effects of state and institutional ownerships on firm performance while the state control is being relinquished gradually. Finally, the study sheds light on the importance of ownership concentration for firm performance when the firm is in transition towards a more market-oriented economy.

The rest of this paper is organized as follows. Section 2 reviews the institutional framework of Chinese market. Section 3 reviews the relevant studies to develop the research hypotheses. Section 4 describes the data and methodology. Empirical results are summarized in section 5. The study concludes in section 6.

\section{Institutional Framework}

China used to follow a central planning oriented economic regime. Founders of the peoples' republic of Chinese adopted this economic regime from the former soviet countries. Under this economic regime, the state simultaneously worked as owners and managers of Chinese companies. The state companies are the legal business entities in Chinese market. However, this economic regime was criticized as the economic development of Chinese market was impaired, since Chinese companies were driven by non-commercial reasons (Xu et al., 2005). Thus, the Chinese government decided to replace it with a market oriented economic regime (Zhang, 2004).

The government adopted the separation of ownership and control to reform Chinese companies, and allowed numerous shareholders to purchase shares of the state owned companies. Some state owned companies that have poor performance were sold to non-state investors. The government also established two stock exchanges in the early 1990s to allow companies to issue stocks on these exchanges, thereby raising funds for the future developments.

The newly privatized companies inherited certain ownership structure from their predecessors. The government retained control in many of the newly privatized companies. Moreover, despites some shares being floated on an exchange, many remains highly restricted from trading. At the beginning of 2005 , shares owned by the government and government-related agencies accounted for more than 70 percent of all non-tradable shares which accounted for more than half of the shares (Jiang et al., 2010).

\section{Literature and Hypotheses}

\subsection{Types of Owner and Firm Performance}

There are two predominant types of owners in post-privatized firms and both are expected to have effects on firm performance.

Under the centrally planned regime, all of the Chinese companies were owned and controlled by the government. The government had undeniable influence on decision making of Chinese companies (Li, 2006). In other words, companies were lack of managerial discretions, but the ownership structure of Chinese companies was simple during that period.

However, the old economic regime was found to have negative impact on firm performance in Chinese companies (Clarke, 2003). To replace the old economic regime, the government began to reform the ownership structure of Chinese companies. Investors were allowed to hold shares of companies. At the same time, the government established two stock exchanges to allow companies issue stocks. Thus, the single ownership structure of Chinese companies became a diversifiable ownership structure.

Despite the potential benefits, there are several drawbacks of this reform. The influence of state on Chinese companies 
is still prevalent widely (Berkman et al., 2010). As a result, managerial decisions of Chinese companies are still oriented towards the interests of the government. Since the government has societal goals above the economic goals, we hypothesize that:

H1: there is a negative relationship between the state shareholdings and firm performance.

In the market economy, the ownership is separated from the control. Companies are managed by the professional managerial team. However, the widespread ownership of listed companies causes the collective supervision infeasible (Hart, 1995). At the same time, the widespread ownership structure generates the problem of free-riders. Individual and small shareholders who either lack interest or the abilities to monitor companies, or both (Hansmann and Kraakman, 2004). Thus, they prefer to rely on other shareholders to monitor the management.

Ownership by institutional investors is mainly through portfolio investments. Institutional investors tend to have low risk aversion and relatively long investment horizon, yet their performance is usually measured by the financial success of their investments. Thus,

\section{H2: there is a positive relationship between the institutional ownership and firm performance.}

\subsection{Share Tradability and Firm Performance}

The transition from the centrally planned regime to a market regime has resulted firms with significant level of non-tradable shares in the hands of the state and state-related owners. The stock segmentation prohibits market mechanism from influencing Chinese companies. Although Chinese companies are listed in stock exchanges, most of stocks could not be exchanged due to non-tradability clause (Chiou and Lin, 2005). Thus, the stock segmentation causes the large shareholders to be entrenched in Chinese companies. This exacerbated the conflicts of interests between large shareholders and small shareholders, thereby damaging firm performance. At the end of 2005, the market regulators of Chinese securities market began to require companies to gradually float the non-tradable shares. This reform is expected to solve the problem of stock segmentation, thereby improving firm performance of Chinese companies. Thus, we hypothesize that:

\section{H3: there is a positive relationship between the tradable shares and firm performance.}

\subsection{Ownership Concentration and Firm Performance}

In the modern listed companies, the ownership is separated from the control. Companies are managed by the professional managerial team. However, the widespread ownership of listed companies causes the collective supervision infeasible (Hart, 1995). At the same time, the widespread ownership structure generates the problem of free-riders. Individual and small shareholders who either lack interest or the abilities to monitor companies, or both (Hansmann and Kraakman, 2004). Thus, they prefer to rely on other shareholders to monitor the management.

One solution of the problem of free-riders is the concentration of ownership. Through the ownership concentration, the shareholders will have enough power to represent the individual and small shareholder in companies, impose sufficient supervision pressure on the managerial team to motivate them to increase firm performance, or replace the managerial team with poor performance. Thus, the concentrated ownership should positively affect firm performance (Gorton and Kahl, 2008; Elyasiani and Jia, 2010).

H4: there is a negative relationship between the ownership concentration and firm performance.

However, an inappropriate ownership concentration can exacerbate the conflicts of interest between large and small shareholders and thereby reducing the firm performance. If shares of listed companies are concentrated in a small group of shareholders, these holders will control the firm. In this case, the interest of small shareholders can be easily expropriated by large shareholders, thereby exacerbating the conflicts of interests between large shareholders and small shareholders. For instance, large shareholders may exacerbate the interest of small shareholders through the related party transaction (Dahya et al., 2008). Thus, ownership concentration can damage firm performance in some cases.

\section{Data and Methodology}

We hand-collected ownership data for non-financial companies from the annual reports for the years 2004-2008. Annual reports of companies give the proportion of the state shareholdings, institutional shareholdings, proportion of tradable shares, and shareholdings of the largest shareholder. After removing incomplete data, the final sample contains 1178 companies. To measure the firm performance, we employ three proxies for firm performance: (1) return on equity (ROE), (2) return on asset (ROA), and (3) the Tobin's Q (Q). Data of ROE and ROA are directly gathered from the annual report. We calculate the Tobin's Q, as in Hovey et al (2003). The cost of replacement can be measured by the total asset, and the market value is equal to share price times the number of ordinary shares (Hovey et al., 2003).

There are three independent variables. Ownership concentration (con) is measured by the percentage shareholdings by the largest shareholder. State ownership (state) is the proportion of shareholdings by the state. Institutional ownership 
(insti) is the percentage of shareholdings by the institutional shareholder. The proportion of tradable share (tradable) is expressed as the proportion of tradable shares in the total shares of a company.

We include a number of control variables. Meyers (1984) state that the companies prefer to issue debt rather than equity to raise fund, and that leverage can influence firm performance. Thus, firm leverage (leverage), calculated as the ratio of debt to total equity, is included as a control. Since in emerging market, large firms can easily have a better performance than small companies (Rochina-Barrachina et al., 2010), firm size (size) measured as the natural logarithm of firm's book value of assets is also included. At the end of 2005, the Chinese companies began to reform their ownership structure. At the same time, the market regulator also promulgated a series of new regulatory roles. To control the influence of these events, the reform dummy (reform) that takes on the value one if the firm is before the year 2005 and zero otherwise is included as another control.

Empirical model estimated can be expressed as:

$$
\begin{gathered}
\text { Performance }_{i t}=\alpha+\beta_{1} \text { Con }_{i t}+\beta_{2} \text { State }_{i t}+\beta_{3} \text { Insti }_{i t}+\beta_{4} \text { Tradable }_{i t}+\beta_{5} \text { Size }_{i t}+\beta_{6} \text { Leverage }_{i t}+ \\
\beta_{7} \text { Reform }_{i t}+\varepsilon_{i t} .
\end{gathered}
$$

where it represents individual firm-year.

Since it could have been that certain ownership structure was attracted by firm performance, Equation (1) is estimated using fixed-effect panel model that can control this form of endogeneity. Due to the high concentration of state ownership, we estimate Equation (1) with either ownership concentration or state ownership to minimize multicollinearity in estimation.

\section{Results}

The sample consists of 5,815 firm-years. Table 1 presents summary statistics on firm performance and ownership structure.

The median state ownership is $36.1 \%$, with the average is $33.6 \%$. This reflects that the state ownership is still a major owner type in the ownership structure in Chinese companies. The average of institutional ownership is 5.9\%, with the median is $2.2 \%$. The average of largest shareholders shareholding is $38.2 \%$ in this sample, which implies that shares are greatly concentrated in a single shareholder.

Table 2 shows the relationship between ownership structure and firm performance in the full sample of this study. As predicted, the institutional ownership has positive effect on all proxies of firm performance. There is no statistical evidence to support the hypotheses that ownership concentration and state ownership damage firm performance in Chinese companies. Tradable shares have statistically significant effect on firm performance, yet the effect is negative, rather than positive. Firm size is found to negatively affect ROA and Q in Chinese companies, but there is no statistically significant relationship between firm size and ROE. Moreover, the indicator for reform is negatively associated with firm performance suggesting that firms in post-reform period have a better performance. Figures from table 2 also show that there is a negative relationship between leverage and firm performance.

Table 1. Descriptive statistics

\begin{tabular}{ccccccc}
\hline & Mean & Median & Maximum & Minimum & Std. Dev. & $\mathrm{N}$ \\
\hline Ownership concentration & 0.382 & 0.361 & 0.852 & 0.008 & 0.159 & 5815 \\
State ownership & 0.336 & 0.361 & 0.970 & 0 & 0.238 & 5815 \\
Institutional ownership & 0.059 & 0.022 & 0.680 & 0 & 0.084 & 5815 \\
Tradable proportion & 0.501 & 0.477 & 1 & 0.025 & 0.170 & 5815 \\
size & 15.342 & 14.404 & 20.438 & 3.934 & 16.852 & 5815 \\
Leverage & 1.624 & 1.023 & 1913.082 & -1671.430 & 35.598 & 5815 \\
\hline
\end{tabular}

Note: Ownership concentration is measured by the percentage shareholdings by the largest shareholder. State ownership is the percentage shareholding by the state. Institutional ownership is the percentage shareholding by the institutional shareholders. The proportion of tradable share, tradable proportion, is expressed as the proportion of tradable shares in the total shares of a company. size is the natural logarithm of total asset of companies. Leverage is the debt-to-equity ratio.

As a robustness check, the whole sample is then divided into two subsamples. The first subsample consists of state owned companies, where the largest shareholder is the state. The second subsample consists of non-state owned companies. Equation (1) is then re-estimated for each subsample and the results for state and non-state companies are represented respectively in Tables 3 and 4.

Results from table 3 show that institutional ownership remains positive in state-owned companies. In state owned companies, there is also a negative relationship between firm performance and proportion of tradable shares. However, concentrated ownership does not improve firm performance in state-owned companies. Again, the state owned companies have better performance after the market reform. Similar results are observed in Table 4 as well. 
Table 2. Relationship between characteristics of ownership structure and firm performance in the full sample

\begin{tabular}{|c|c|c|c|c|c|c|c|c|c|c|c|c|}
\hline \multirow[b]{2}{*}{ Con } & \multicolumn{4}{|c|}{ Dependent: ROE } & \multicolumn{4}{|c|}{ Dependent: ROA } & \multicolumn{4}{|c|}{ Dependent: Q } \\
\hline & $\begin{array}{c}0.288 \\
(1.407)\end{array}$ & & & & $\begin{array}{c}0.278 \\
(1.052)\end{array}$ & & & & $\begin{array}{c}0.087 \\
(0.750)\end{array}$ & & & \\
\hline State & & & $\begin{array}{c}0.067 \\
(0.447)\end{array}$ & & & & $\begin{array}{c}0.240 \\
(1.197)\end{array}$ & & & & $\begin{array}{c}-0.001 \\
(-0.016)\end{array}$ & \\
\hline Insti & $\begin{array}{c}0.018 \\
(1.742)\end{array}$ & $*$ & $\begin{array}{c}0.019 \\
(1.809)\end{array}$ & $*$ & $\begin{array}{c}0.117 \\
(8.642)\end{array}$ & $* * *$ & $\begin{array}{c}0.118 \\
(8.723)\end{array}$ & $* * *$ & $\begin{array}{c}0.067 \\
(11.070)\end{array}$ & $* * *$ & $\begin{array}{c}0.067 \\
(11.088)\end{array}$ & $* * *$ \\
\hline Tradable & $\begin{array}{c}-0.191 \\
(-3.113)\end{array}$ & $* * *$ & $\begin{array}{c}-0.214 \\
(-3.612)\end{array}$ & $* * *$ & $\begin{array}{c}-0.388 \\
(-4.967)\end{array}$ & $* * *$ & $\begin{array}{c}-0.396 \\
(-5.219)\end{array}$ & $* * *$ & $\begin{array}{c}-0.294 \\
(-8.390)\end{array}$ & $* * *$ & $\begin{array}{c}-0.303 \\
(-8.966)\end{array}$ & $* * *$ \\
\hline size & $\begin{array}{l}-0.032 \\
(-0.943)\end{array}$ & & $\begin{array}{l}-0.029 \\
(-0.845)\end{array}$ & & $\begin{array}{c}-0.520 \\
(-13.395)\end{array}$ & $* * *$ & $\begin{array}{c}-0.517 \\
(-13.380)\end{array}$ & $* * *$ & $\begin{array}{c}-0.475 \\
(-28.913)\end{array}$ & $* * *$ & $\begin{array}{c}-0.474 \\
(-28.951)\end{array}$ & $* * *$ \\
\hline Leverage & $\begin{array}{c}-0.016 \\
(-13.330)\end{array}$ & $* * *$ & $\begin{array}{c}-0.016 \\
(-13.319)\end{array}$ & $* * *$ & $\begin{array}{c}-0.010 \\
(-2.792)\end{array}$ & $* * *$ & $\begin{array}{c}-0.010 \\
(-2.765)\end{array}$ & $* * *$ & $\begin{array}{c}0.000 \\
(0.874)\end{array}$ & & $\begin{array}{c}0.000 \\
(0.868)\end{array}$ & \\
\hline reform & $\begin{array}{c}-0.103 \\
(-3.341)\end{array}$ & $* * *$ & $\begin{array}{c}-0.096 \\
(-3.108)\end{array}$ & $* * *$ & $\begin{array}{c}-0.300 \\
(-7.660)\end{array}$ & $* * *$ & $\begin{array}{c}-0.301 \\
(-7.708)\end{array}$ & $* * *$ & $\begin{array}{c}-0.509 \\
(-29.797)\end{array}$ & $* * *$ & $\begin{array}{c}-0.506 \\
(-29.686)\end{array}$ & $* * *$ \\
\hline $\begin{array}{l}\text { Constant } \\
\text { Adj. } R^{2}\end{array}$ & $\begin{array}{c}0.405 \\
(0.805) \\
0.92\end{array}$ & & $\begin{array}{c}0.427 \\
(0.848) \\
0.92\end{array}$ & & $\begin{array}{c}4.163 \\
7.233 \\
0.51\end{array}$ & $* * *$ & $\begin{array}{c}4.146 \\
7.197 \\
0.51\end{array}$ & $* * *$ & $\begin{array}{c}7.681 \\
31.674 \\
0.58\end{array}$ & $* * *$ & $\begin{array}{c}7.692 \\
31.707 \\
0.58\end{array}$ & $* * *$ \\
\hline $\begin{array}{l}*, * * \text {, and } \\
\text { Table } 3 .\end{array}$ & $\begin{array}{l}\text { represent } \\
\text { nership s }\end{array}$ & $\begin{array}{l}\text { ignifi } \\
\text { uctu }\end{array}$ & $\begin{array}{l}\text { ce at } 10 \% \\
\text { nd firm }\end{array}$ & $\begin{array}{l}5 \% \text { a } \\
\text { rfor }\end{array}$ & $\begin{array}{l}\%, \text { respect } \\
\text { ce in stat }\end{array}$ & $\begin{array}{l}\text { tively. } \\
\text { e-own }\end{array}$ & ompanie & & & & & \\
\hline & & Depen & nt: ROE & & & Depenc & ent: ROA & & & Depe & dent: Q & \\
\hline Con & $\begin{array}{l}0.328 \\
1.136\end{array}$ & & & & $\begin{array}{l}0.480 \\
1.557\end{array}$ & & & & $\begin{array}{l}0.024 \\
0.165\end{array}$ & & & \\
\hline State & & & $\begin{array}{l}0.394 \\
1.355\end{array}$ & & & & $\begin{array}{l}0.452 \\
1.445\end{array}$ & & & & $\begin{array}{l}0.087 \\
0.601\end{array}$ & \\
\hline Insti & $\begin{array}{l}0.093 \\
6.615\end{array}$ & $* * *$ & $\begin{array}{l}0.094 \\
6.677\end{array}$ & $* * *$ & $\begin{array}{l}0.099 \\
6.543\end{array}$ & $* * *$ & $\begin{array}{l}0.100 \\
6.610\end{array}$ & $* * *$ & $\begin{array}{c}0.071 \\
10.086\end{array}$ & $* * *$ & $\begin{array}{c}0.071 \\
10.105\end{array}$ & $* * *$ \\
\hline Tradable & $\begin{array}{l}-0.263 \\
-3.154\end{array}$ & $* * *$ & $\begin{array}{l}-0.248 \\
-2.894\end{array}$ & $* * *$ & $\begin{array}{l}-0.314 \\
-3.506\end{array}$ & $* * *$ & $\begin{array}{l}-0.307 \\
-3.327\end{array}$ & $* * *$ & $\begin{array}{l}-0.279 \\
-6.523\end{array}$ & $* * *$ & $\begin{array}{l}-0.271 \\
-6.191\end{array}$ & $* * *$ \\
\hline size & $\begin{array}{l}-0.060 \\
-1.279\end{array}$ & & $\begin{array}{l}-0.065 \\
-1.362\end{array}$ & & $\begin{array}{l}-0.271 \\
-5.375\end{array}$ & $* * *$ & $\begin{array}{l}-0.274 \\
-5.402\end{array}$ & $* * *$ & $\begin{array}{c}-0.316 \\
-14.186\end{array}$ & $* * *$ & $\begin{array}{c}-0.317 \\
-14.192\end{array}$ & $* * *$ \\
\hline Leverage & $\begin{array}{l}-0.001 \\
-0.318\end{array}$ & & $\begin{array}{l}-0.001 \\
-0.317\end{array}$ & & $\begin{array}{l}-0.009 \\
-1.906\end{array}$ & & $\begin{array}{l}-0.009 \\
-1.906\end{array}$ & & $\begin{array}{l}0.000 \\
1.111\end{array}$ & & $\begin{array}{l}0.000 \\
1.116\end{array}$ & \\
\hline reform & $\begin{array}{l}-0.176 \\
-4.030\end{array}$ & $* * *$ & $\begin{array}{l}-0.180 \\
-4.105\end{array}$ & $* * *$ & $\begin{array}{l}-0.202 \\
-4.308\end{array}$ & $* * *$ & $\begin{array}{l}-0.201 \\
-4.270\end{array}$ & $* * *$ & $\begin{array}{c}-0.439 \\
-20.700\end{array}$ & $* * *$ & $\begin{array}{c}-0.442 \\
-20.839\end{array}$ & $* * *$ \\
\hline $\begin{array}{l}\text { Constant } \\
\text { Adj. } R^{2}\end{array}$ & $\begin{array}{c}-1.836 \\
-2.590 \\
0.56\end{array}$ & $* * *$ & $\begin{array}{c}-1.803 \\
-2.549 \\
0.56\end{array}$ & $* * *$ & $\begin{array}{c}0.393 \\
0.521 \\
0.56\end{array}$ & $* * *$ & $\begin{array}{c}0.436 \\
0.579 \\
0.56\end{array}$ & $* * *$ & $\begin{array}{c}5.392 \\
16.151 \\
0.54\end{array}$ & $* * *$ & $\begin{array}{c}5.387 \\
16.162 \\
0.54\end{array}$ & $* * *$ \\
\hline $\begin{array}{l}*, * * \text {, anc } \\
\text { Table } 4 .\end{array}$ & $\begin{array}{l}\text { epresent } \\
\text { ership s }\end{array}$ & $\begin{array}{l}\text { gnif } \\
\text { uctu }\end{array}$ & $\begin{array}{l}\text { e at } 10 \% \\
\text { d firm }\end{array}$ & $\begin{array}{l}5 \% \\
\text { rffor }\end{array}$ & $\begin{array}{l}\%, \text { respe } \\
\text { ce in pr }\end{array}$ & $\begin{array}{l}\text { tively. } \\
\text { vate co }\end{array}$ & hies & & & & & \\
\hline & & Depend & nt: ROE & & & epender & ROA & & & Depe & lent: Q & \\
\hline Con & $\begin{array}{l}-0.556 \\
-0.983\end{array}$ & & & & $\begin{array}{l}-0.377 \\
-0.650\end{array}$ & & & & $\begin{array}{l}0.408 \\
1.632\end{array}$ & & & \\
\hline State & & & $\begin{array}{l}1.049 \\
1.719\end{array}$ & $*$ & & & $\begin{array}{l}0.895 \\
1.403\end{array}$ & & & & $\begin{array}{l}-0.143 \\
-0.511\end{array}$ & \\
\hline Insti & $\begin{array}{l}0.153 \\
5.654\end{array}$ & $* * *$ & $\begin{array}{l}0.152 \\
5.647\end{array}$ & $* * *$ & $\begin{array}{l}0.161 \\
5.745\end{array}$ & $* * *$ & $\begin{array}{l}0.161 \\
5.761\end{array}$ & $* * *$ & $\begin{array}{l}0.059 \\
4.822\end{array}$ & $* * *$ & $\begin{array}{l}0.061 \\
4.981\end{array}$ & $* * *$ \\
\hline Tradable & $\begin{array}{l}-0.483 \\
-3.143\end{array}$ & $* * *$ & $\begin{array}{l}-0.420 \\
-2.969\end{array}$ & $* * *$ & $\begin{array}{l}-0.356 \\
-2.217\end{array}$ & $* *$ & $\begin{array}{l}-0.313 \\
-2.106\end{array}$ & $* *$ & $\begin{array}{l}-0.224 \\
-3.196\end{array}$ & $* * *$ & $\begin{array}{l}-0.270 \\
-4.158\end{array}$ & $* * *$ \\
\hline size & $\begin{array}{l}-0.195 \\
-1.924\end{array}$ & $*$ & $\begin{array}{l}-0.214 \\
-2.141\end{array}$ & $* *$ & $\begin{array}{c}-0.975 \\
-13.579\end{array}$ & $* * *$ & $\begin{array}{c}-0.983 \\
-13.882\end{array}$ & $* *$ & $\begin{array}{c}-0.612 \\
-20.137\end{array}$ & $* *$ & $\begin{array}{c}-0.602 \\
-20.152\end{array}$ & $* *$ \\
\hline Leverage & $\begin{array}{l}0.020 \\
1.548\end{array}$ & & $\begin{array}{l}0.019 \\
1.510\end{array}$ & & $\begin{array}{l}-0.012 \\
-1.987\end{array}$ & $*$ & $\begin{array}{l}-0.012 \\
-2.011\end{array}$ & $* *$ & $\begin{array}{l}-0.001 \\
-0.516\end{array}$ & & $\begin{array}{l}-0.001 \\
-0.492\end{array}$ & \\
\hline reform & $\begin{array}{l}-0.126 \\
-1.635\end{array}$ & & $\begin{array}{l}-0.147 \\
-1.908\end{array}$ & $*$ & $\begin{array}{l}-0.296 \\
-3.845\end{array}$ & $* * *$ & $\begin{array}{l}-0.313 \\
-4.042\end{array}$ & $* * *$ & $\begin{array}{c}-0.536 \\
-15.924\end{array}$ & $* * *$ & $\begin{array}{c}-0.531 \\
-15.678\end{array}$ & $* * *$ \\
\hline Constant & $\begin{array}{l}0.439 \\
0.300\end{array}$ & & $\begin{array}{l}0.523 \\
0.358\end{array}$ & & $\begin{array}{l}10.925 \\
10.551\end{array}$ & $* * *$ & $\begin{array}{l}10.907 \\
10.543\end{array}$ & $* * *$ & $\begin{array}{c}9.454 \\
21.975\end{array}$ & $* * *$ & $\begin{array}{c}9.428 \\
21.906\end{array}$ & $* * *$ \\
\hline Adj. $R^{2}$ & 0.52 & & $\begin{array}{l}0.550 \\
0.52\end{array}$ & & 0.47 & & 0.47 & & 0.65 & & 0.65 & \\
\hline
\end{tabular}

$*, * *$, and $* * *$ represent significance at $10 \%, 5 \%$ and $1 \%$, respectively.

\section{Conclusion and Discussion}

The separation of ownership and control is a fundamental characteristic of modern listed companies. Large companies have a plenty of shareholders who have various interests. Thus, the ownership structure will affect the extent to which the conflict of interest prevails in companies, thereby affecting firm performance. Previous studies indicate that 
ownership concentration tends to damage firm performance in companies (Dahya et al., 2008). Conversely, institutional ownership has positive impacts on firm performance (Gorton and Kahl, 2008; Elyasiani and Jia, 2010).

Using a sample of 5815 firm-years we investigate the effect of ownership structure on firm performance as measured by the return on equity, return on asset and Tobin's Q. As anticipated, institutional ownership improves firm performance. However, concentrated ownership and state ownership do not deteriorate firm performance as postulated. Also unexpected is the effect of tradable shares on firm performance. The reduction in non-tradable shares is expected to positively affect firm performance but the results suggest otherwise.

\section{State ownership and firm performance}

Results from this study indicate that state ownership does not deteriorate firm performance, even in the state owned companies. This might partly be explained by the fact that the firms have relatively recently transited from a centrally planned economy to a market economy. In centrally planned economy, the state controlled resource allocation for the country, which benefited state companies. Even after de-centralization, state involvement has shown to enable firms with better access to the resources needed (Li et al., 2008). Thus, the state ownership might have helped firms access the resources they need to improve firm performance while their economic performance is deteriorated through diversion of resources to societal welfare performance.

\section{Ownership concentration and firm performance}

Contrary to the previous studies, our results indicate no relationship between ownership concentration and firm performance. This could be due to the level of investor protections. Ownership concentration can impose more supervision pressure on managerial team and reduce the conflict of interests between shareholders and managerial team. However, the ownership concentration can exacerbate the conflicts of interest between large shareholders and small shareholders when investor protections are weak. As a consequence, the conflicts of interest between shareholders may exacerbate the agency cost, thereby harming firm performance.

\section{Institutional ownership and firm performance}

We find a positive relationship between institutional ownership and firm performance. This is consistent with previous studies (Gorton and Kahl, 2008; Elyasiani and Jia, 2010). Instructional ownership has the following potential benefits to companies. Firstly, institutional investors have abilities to effectively oversee the managerial team of companies. When their shareholdings are large enough, they can impose supervision pressure on managerial team. Thus, institutional shareholders motivate executives of companies to increase firm performance. Secondly, institutional shareholding may reduce the conflicts of interest between large shareholders and small shareholders. Compare with individual shareholders, shareholdings of institutional shareholders are relatively large. Thus, institutional shareholders can represent individual shareholders in monitoring the firm (Admati et al., 1994). And institutional investors investing through portfolio investments are evaluated on the performance of their investment portfolios. Under this circumstance, the conflict of interests between large shareholders and small shareholders might be reduced, thereby, improving firm performance.

\section{Tradable shares and firm performance}

This study finds that an increase in the proportion of tradable shares in the companies has negative effect on firm performance. The purpose of the reduction of non-tradable shares is to reduce the negative impact of stock segmentation on the companies. Thus, the reduction of non-tradable shares is expected to have positive effect on firm performance. However, the empirical results are converse to the expectation. A possible reason for this is the characteristics of investors in the securities markets. The majority of Chinese investors are individual and small shareholders (Zhang et al, 2010). The reduction of non-tradable shares increase liquidity of the Chinese securities markets, since the number of shares traded increases. More unsophisticated investors are attracted to join the markets (Zhang et al, 2010). This may exacerbate the problem of free-rider, consequently impairing the quality of monitoring of the firms. If shareholders cannot effectively monitor executives of companies, there will be serious conflicts of interest between shareholders and executive, thereby lowering firm performance.

\section{Reference}

Admati, A. R., Pfleiderer, P., \& Zechner, J. (1994). Large shareholder activism, risk sharing, and financial market equilibrium. Journal of Political Economy, 102(6),1097-1130. https://doi.org/10.1086/261965

Berkman, H., Cole, R. A., \& Fu, J. L. (2009). Political Connections and Minority-Shareholder Protection: Evidence from Securities-Market Regulation in China. Journal of Financial and Quantitative Analysis, 45(6), 1391-1417. https://doi.org/10.1017/S0022109010000608

Berkman, H., Cole, R. A., \& Fu, J. L. (2010). Improving Corporate Governance Where the State is the Controlling Block Holder: Evidence from China (March 26, 2010). Second Singapore International Conference on Finance 
2008. Available online at: SSRN: http://ssrn.com/abstract=1020170. (Accessed: 15-Dec 2010)

Chang, E. C., \& Wong, S. M. L. (2004). Political control and performance in China's listed firms. Journal of Comparative Economics, 32(4), 617-636. https://doi.org/10.1016/j.jce.2004.08.001

Chen-Lung, C., Yu, J. C., \& Tsun-Jui, H. (2009). International Diversification, Ownership Structure, Legal Origin, and Earnings Management: Evidence from Taiwan. Journal of Accounting, Auditing \& Finance, 24, 233-362.

Chen, X., Kim, J. B., Wang, S. S., \& Xu, X. (2007). Firm performance and the ownership of the largest shareholder. Corporate Ownership \& Control, 4(3), 126-138.

Chiou, J. R., \& Lin, Y. H. (2005). The Structure of Corporate Ownership: A Comparison of China and Taiwan's Security Markets. Journal of American Academy of Business, Cambridge, 6(2), 123-127.

Clarke, D. C. (2003). Corporate Governance in China: An Overview. Available online at: http://ssrn.com/paper=424885. (Accessed: 1-Aug 2009)

Dahya, J., Dimitrov, O., \& McConnell, J. J. (2008). Dominant shareholders, corporate boards, and corporate value: A cross-country analysis. Journal of Financial Economics, 87(1), 73-100. https://doi.org/10.1016/j.jfineco.2006.10.005

Elyasiani, E., \& Jia, J. (2010). Distribution of institutional ownership and corporate firm performance. Journal of Banking \& Finance, 34(3), 606-620. https://doi.org/10.1016/j.jbankfin.2009.08.018

Gorton, G., \& Kahl, M. (2008). Blockholder Scarcity, Takeovers, and Ownership Structures. Journal of Financial \& Quantitative Analysis, 43(4), 937-974. https://doi.org/10.1017/S002210900001440X

Hansmann, H., \& Kraakman, R. H. (2004). Agency Problems and Legal Strategies. In: R. Kraalman, P. Davies, H. Hansmann, G. Hertig, K. Hopt, H. Kanda and E. Rock (Eds). The Anatomy of Coporate Law: A Comparative and Functional Approach. Oxford University Press, Oxford. 21-31.

Hart, O. (1995). Corporate Governance: Some Theory and Implications. The Economic Journal, 105(430), 678-689. https://doi.org/10.2307/2235027

Hovey, M., Li, L., \& Naughton, T. (2003). The Relationship Between Valuation and Ownership of Listed Firms in China. Corporate Governance: An International Review, 11(2), 112-122. https://doi.org/10.1111/1467-8683.00012

Huang, A. G., \& Fung, H. G. (2005). Floating the Nonfloatables in China's Stock Market: Theory and Design. Emerging Markets Finance \& Trade, 41(5), 6-26.

Jiang, G., Lee, C., \& Yue, H. (2010). Tunneling through intercorporate loans: The China experience. Journal of Financial Economics, 98, 1-20. https://doi.org/10.1016/j.jfineco.2010.05.002

Li, H., Meng, L., Wang, Q., \& Zhou, L. A. (2008). Political connections, financing and firm performance: Evidence from Chinese private firms. Journal of Development Economics, 87(2), $283-299$. https://doi.org/10.1016/j.jdeveco.2007.03.001

Li, W. (2006). The market-oriented governance model of SOEs: China perspective. Corporate Ownership \& Control, 3(4), 108-122.

López-de-Foronda, Ó., López-Iturriaga, F. J., \& Santamaría-Mariscal, M. (2007). Ownership Structure, Sharing of Control and Legal Framework: international evidence. Corporate Governance: An International Review, 15(6), 1130-1143. https://doi.org/10.1111/j.1467-8683.2007.00636.x

Meyers, S. C. (1984). The Capital Structure Puzzle. Journal of Finance, 39, 575-592. https://doi.org/10.2307/2327916

$\mathrm{Ng}$, A., Yuce, A., \& Chen, E. (2009). Determinants of state equity ownership, and its effect on value/performance: China's privatized firms. Pacific-Basin Finance Journal, 17, 413-443. https://doi.org/10.1016/j.pacfin.2008.10.003

Rochina-Barrachina, M., Mañez, J., \& Sanchis-Llopis, J. (2010). Process innovations and firm productivity growth. Small Business Economics, 34(2), 147-166. https://doi.org/10.1007/s11187-008-9110-5

Tomasic, R. A., \& Fu, J. J. R. (2006). Government-owned companies and corporate governance in Australia and China: Beyond fragmented governance. Corporate Ownership \& Control, 3(4), 123-131.

Xu, L. C., Zhu, T., \& Lin, Y. M. (2005). Politician control, agency problems and ownership reform. Economics of Transition, 13(1), 1-24. https://doi.org/10.1111/j.1468-0351.2005.00205.x

Yeh, Y., Shu, P., Lee, T., \& Su, Y. (2009). Non-tradable share reform and corporate governance in the Chinese stock market. Corporate Governance: An International Review, 17(4), 457-475. https://doi.org/10.1111/j.1467-8683.2009.00754.x 
Zhang, L. Y. (2004). The Roles of Corporatization and Stock Market Listing in Reforming China's State Industry. World Development, 32(12), 2031-2047. https://doi.org/10.1016/j.worlddev.2004.08.003

Zhang, Y. J., Liu, X. D., Zhou, Q. Y., Wan, D. J., Liu, S. A., Xie, W., \& Xu, M. (2010). Shanghai Stock Exchange Statistics Annual 2009. Shanghai Stock Exchanges, Shanghai. 398

\section{Copyrights}

Copyright for this article is retained by the author(s), with first publication rights granted to the journal.

This is an open-access article distributed under the terms and conditions of the Creative Commons Attribution license which permits unrestricted use, distribution, and reproduction in any medium, provided the original work is properly cited. 